\title{
NO SUSTAINABILITY FOR TOURISM WITHOUT GENDER EQUALITY
}

\begin{tabular}{|c|c|}
\hline Journal: & Journal of Sustainable Tourism \\
\hline Manuscript ID & JOST-4246.R2 \\
\hline Manuscript Type: & Special Issue Paper \\
\hline Keywords: & Tourism from a gender perspective, SDGs, Human Rights, SDG 5 \\
\hline Highlights for Twitter: & $\begin{array}{l}\text { NO SUSTAINABILITY FOR TOURISM WITHOUT GENDER EQUALITY, Why } \\
\text { Sustainable tourism is not possible if gender remains as an additional } \\
\text { element, Tourism from a gender perspective and SDGs, SDG } 5+ \\
\text { TOURISM }\end{array}$ \\
\hline Abstract: & $\begin{array}{l}\text { This paper explores the interconnections between the Sustainable } \\
\text { Development Goals (SDGs) and tourism from a gender perspective. It is } \\
\text { the first paper to take a critical analysis of how SDG } 5 \text { relates to tourism, } \\
\text { and how tourism and gender equality interconnects with the other SDGs. } \\
\text { First, we analyze the recent gender sensitive sustainable development } \\
\text { agenda in order to set out the challenges - both past and present - that } \\
\text { any sector involved in sustainable development faces. We then explore } \\
\text { the links between the SDGs and tourism development from a gender } \\
\text { perspective. In the third part of the paper, based on the field } \\
\text { experiences of the authors, we use the examples of SDG } 6 \text { ('clean water } \\
\text { and sanitation') and SDG } 8 \text { ('sustainable economic growth and decent } \\
\text { work') to highlight the interconnections between gender equality and the } \\
\text { other SDGs. Finally, we suggest some tools to help tourism businesses } \\
\text { improve their performance with respect to gender equality thereby } \\
\text { enhancing their capacity to contribute towards the achievement of the } \\
\text { SDGs. We argue that, without tackling gender equality in a meaningful } \\
\text { and substantive way, tourism's potential to contribute to the SDGs will } \\
\text { be reduced and sustainable tourism will remain an elusive 'pot of gold'. }\end{array}$ \\
\hline
\end{tabular}

\section{SCHOLARONE" Manuscripts}




\title{
No sustainability for tourism without gender equality
}

\begin{abstract}
This paper explores the interconnections between the Sustainable Development Goals (SDGs) and tourism from a gender perspective. It is the first paper to take a critical analysis of how SDG 5 relates to tourism, and how tourism and gender equality interconnects with the other SDGs. First, we analyze the recent gender sensitive sustainable development agenda in order to set out the challenges - both past and present - that any sector involved in sustainable development faces. We then explore the links between the SDGs and tourism development from a gender perspective. In the third part of the paper, based on the field experiences of the authors, we use the examples of SDG 6 ('clean water and sanitation') and SDG 8 ('sustainable economic growth and decent work') to highlight the interconnections between gender equality and the other SDGs. Finally, we suggest some tools to help tourism businesses improve their performance with respect to gender equality thereby enhancing their capacity to contribute towards the achievement of the SDGs. We argue that, without tackling gender equality in a meaningful and substantive way, tourism's potential to contribute to the SDGs will be reduced and sustainable tourism will remain an elusive 'pot of gold'.
\end{abstract}

Keywords: Tourism from a gender perspective, SDGs, SDG 5, Human Rights.

\section{Introduction}

Gender and tourism studies have grown considerably over the past 20 years (Burrell et al., 1997; Gibson, 2001; Ferguson, 2009; Harvey, Hunt \& Harris 1995; Kinnaird \& Hall, 1994, 1996; Lakovidou \& Turner, 1995; Norris, Wall, Cooper \& Lockwood, 1994; Nozawa, 1995; Pritchard et al., 2007; Scheyvens, 2007; Sinclair, 1997; Swain, 1993, 1995, 2007; Swain \& 
Hall, 2007; Wilkinson \& Pratiwi, 1995). Gender and tourism studies have opened doors for better understanding the opportunities, and the challenges, confronting tourism stakeholders in terms of poverty reduction (Tucker \& Boonabaana, 2012); policy-making and projects (Ferguson, 2010a, 2010b, 2011; Ferguson \& Moreno, 2015), and decent working conditions (Carvalho, Costa, Lykke \& Torres, 2014; Gentry, 2007; Huete, Broto \& Sigüenza, 2016; Iverson, 2000; Jordan, 1997; Ladkin, 2011; Moreno \& Cañada, 2018; Muñoz- Bullón, 2009; Purcell, 1996; Skalpe, 2007; Thrane, 2008; Vandegrift, 2008).

As widely recognized in the literature, without gender equality there can be no sustainability (Bidegain Ponte \& Rodríguez Enríquez, 2016; Bidegain Ponte, 2017; UN Women, 2018b). The number of academic journal articles exploring gender, tourism and empowerment has grown in recent years (Tucker \& Boonabaana, 2012; Feng, 2013; Trans \& Walter, 2014; Ramos \& Prideaux, 2014; Moswete \& Lacey, 2015; Knight \& Cottrell, 2016; Panta \& Thapa, 2017; Figueroa-Domecq, Pritchard, Segovia-Pérez, Morgan \& Villacé Molinero, 2015; Movono \& Dahles, 2017). Nonetheless, the implications of these research findings have not been sufficiently understood and translated into policy and practice at all levels of the tourism industry. A great deal of gender and tourism analysis is emerging in tourism (Figueroa et al, 2015; Suárez et al, 2016), but this is not the case in the field where there is a dearth of gender sensitive policies. Thus it is vital to champion gender equality in the context of tourism and the Sustainable Development Goals (SDGs). The global context of sustainability, reflected in the SDGs, makes it imperative to integrate gender equality within the SDGs and tourism development (UNWTO, 2017, 2018). From an academic point of view, little attention has been paid to clarifying the significance of the SDGs for 'gender responsible tourism', or consideration given to the broader context of the sustainable development of tourism from a gender perspective. Few academics have considered the broader policy environment or made 
links to structural barriers (Swain, 2004), or to intersectionality. The most significant structural barriers to gender equality are: eliminating all forms of violence against women and addressing unpaid care and domestic work (UN Women, 2018b). Intersectionality refers to women's multiple, mutually constructed systems of subordination and thus how multiple demographic factors such as race, ethnicity, age, education and ability mediate experiences of equality and empowerment (Cole, 2017; Mooney, 2018). Thus women are not understood as a homogenous group, and context specific intersectional approaches allow for critical unpacking of social relations, justice and power. The "leave no-one behind" pledge within the SDGs attempts to focus attention on those who have been historically marginalized and hence is committing to an intersectional approach.

The United Nations' declaration of 2017 as the Year of Sustainable Tourism for Development (IY2017) reflected tourism's importance as a sector capable of contributing to sustainable development, including human rights. However, while the importance of gender equality has been widely recognized as integral to sustainability, relatively few tourism structures have embraced gender equality and women's empowerment (Ferguson \& Moreno, 2015; Equality in Tourism, 2017; Ferguson, 2018). This is problematic when tourism projects and policy are developed in the field (Ferguson \& Moreno, 2015; Moreno, 2018b). Frequently, actions undertaken to improve the conditions of women working in tourism are not to be based on sound gender analysis, which is a prerequisite for meaningfully improving women's positions. For example, in Spain, many hotels' CSR policies include the creation of women's executive networks, but make no reference to the discrimination faced by women workers on a daily basis (Ferguson \& Moreno, 2016). 
The main objective of this paper is to highlight the importance of SDG 5, gender equality, for the development of tourism and its relationship to the other SDGs. By first examining the place of gender equality in the SDGs and the interconnection between SDG5 and the other SDGs, the paper then explores these interconnections in relation to sustainable tourism. In doing so this paper highlights that SDG 5 is a critical component of sustainable tourism and offers some first steps businesses can take to support SDG 5.

It is our contention that a feminist perspective is required in tourism development (Aitchison, 2005; Swain, 2007) in order to ensure tourism's sustainability. According to Moreno (2018a, p. 25) "Gender equality without feminism is confined to reproducing and making invisible the gaps between men and women. This also draws, for example, on the fact that having more or only women in a specific initiative does not guarantee gender equality if the symbolic and normative codes promoted by patriarchy are not analyzed as the main challenges for reducing poverty in developed and developing countries". This may be one of the reasons, as Figueroa-Domecq et al. (2015) have argued, there is a little dialogue between some gender and tourism researchers and 'those in the wider social sciences' and the lack of "transformative feminist politics in international development institutions" (Ferguson 2014, P. 380).

Drawing on the literature in gender mainstreaming that points out the importance of gender equality being a core component not an add-on (Standing, 2004; Daly, 2005; Caglar, Prügl \& Zwingel, 2013; Mukhopadhyay, 2013; Hoard, 2015) this paper argues that sustainable tourism is not possible if gender remains an 'additional' element for sustainable tourism development, or if the veneer of gender is used as a way of silencing feminism. The 'time's up now' for gender equality in tourism because tourism has sought to champion sustainable 
development from economic, social and environment standpoints, but gender equality frequently remains completely absent when sustainability is pursued by tourism stakeholders (Hardy, Beeton \& Pearson, 2002; Ruhanen, Weiler, Moyle \& McLennan, 2015).

The methodology of this paper is based on the experiences of participatory, first-hand practical and theoretical research, grounded in fieldwork. It draws upon the authors' extensive experience as academics, as well as gender and tourism consultants, who have worked in diverse countries and contexts over the past decade in international development. The focus on SDG 6 and 8 is based on our most recent and in depth fieldwork (for more details of the fieldwork see Moreno 2017a and Cole 2017).

The article will contribute to the growing body of literature on the role of tourism to contribute to the SDGs aiming to improve the lives of both women and men, while encouraging the sustainable development of tourism as a whole. It offers tools to tourism businesses to support their responsibilities to achieve the SDGs and will also provide inputs for policy-makers who are willing to transform tourism by integrating a gender perspective. First, we begin by analyzing the recent gender sensitive sustainable development agenda in order to set out the challenges facing all sectors involved in sustainable development. Second, we explore the links between the SDGs and tourism development from a gender perspective. The third part of the paper explores gender and tourism using the context of SDG 6 ('clean water and sanitation') and SDG 8 ('sustainable economic growth and decent work') as two examples, to expose how gender equality plays a pivotal role in achieving all the SDGs. We then suggest some tools tourism businesses can use to support their responsibilities for achieving the SDGs. 


\section{The sustainable development agenda underpinned by a feminist lens}

In 2000, the United Nations General Assembly, representing 191 governments, adopted the Millennium Declaration. With its eight Millennium Development Goals (MDGs), 18 targets and 48 indicators, the Declaration affirmed global aims to be reached by 2015 . The Millennium Declaration outlined mechanisms to guarantee women's and men's equal access to rights and opportunities, as well as to end violence against women through the implementation of the Convention on the Elimination of all Forms of Discrimination Against Women (CEDAW) (United Nations, 2000).

The understanding of gender equality as a human right was affirmed in the framework of Millennium Development Goals (MDG) 5, 'improve maternal health', and target 3.A 'eliminate gender disparity in primary and secondary education...'. The MDGs therefore, were gender-guided in terms of the promotion of maternal health and girls' education. Understood from a feminist perspective, however, the MDGs established distractions from their own aims due to a lack of feminist analysis (Antrobus, 2006; Ariffin, 2004; Kabeer, 2015; Mujeres en Red, 2005). According to De la Cruz (2015), the definition and application of the MDGs generated an important debate at the core of the women's movement. For some, the MDGs were a reduction of the recommendations agreed upon during the 1990s through the Beijing Platform for Action. For others, the MDGs represented an opportunity for promoting action plans and mobilizing resources in line with the feminist agenda, as envisaged at the United Nations Conferences in Cairo in 1994, in Copenhagen in 1995, and during the follow-up meetings of the original Beijing Conference in 1995, known as Beijing +5 and Beijing +10 . 
The weakness of the MDGs lies in the lack of theoretical and practical connections between poverty, gender equality and women's lives. Whereas the Beijing Platform for Action was "based on a strong body of evidence that spelt out the complex and interdependent causalities underlying women's subordinate status across the world there was no such clear analytical logic to the MDGs" (Kabeer, 2015 p. 389). For example, the MDGs entailed a perception of maternal health or death devoid of causal elements, which suggested that the starting point for achieving improved maternal health, was at the point of pregnancy. The MDGs did not take into consideration important contextual, sexual and reproductive rights (FernándezLayos \& Ruiz, 2011). Another critique was directed at some of the indicators applied in assessing women's access to employment. For example, indicator 3.2 refers to the 'share of women in wage employment in the non-agricultural sector', such as, for example, the service sector. However, as pointed out by UNIFEM (2000), access to income and salaries linked to the service industry does not necessarily imply emancipation because this sector is strongly linked with other forms of subordination.

The 2030 Agenda for Sustainable Development, adopted in September 2015 by the United Nations General Assembly, encompasses 17 Sustainable Development Goals (SDGs) and their 169 corresponding targets. These aim "to build on the Millennium Development Goals and complete what they did not achieve. They seek to realize the human rights of all and to achieve gender equality and the empowerment of all women and girls. They are integrated and indivisible and balance the three dimensions of sustainable development: the economic, social and environmental" (United Nations, 2015b, p. 2). As stated, "the achievement of full human potential and of sustainable development is not possible if one half of humanity continues to be denied its full human rights and opportunities" (ibid p. 6). 
In order to more successfully identify women's differing needs, the SDGs are grounded upon a process of contextualization and conceptualization with respect to the links between poverty and gender equality (Chant, 2008). According to the Post-2015 Women's Coalition (2015), this process was vital to ensure that sustainable development truly means human development, environmental protection and social development. As a result, and given Agenda 2030's universal approach, it is no longer a North-South aid agenda. Rather, the SDGs offer significant possibilities for a more transformative and broader change agenda (Fukuda-Parr, 2016). The following measures are outlined by the United Nations aimed at integrating gender equality and women's empowerment into the SDGs:

- The improvement of women's capacities and their enjoyment of all human rights.

- The assessment, reduction and redistribution of unpaid care work performed by women and girls.

- The full and equal participation of women in sustainable development as agents and decision-makers in the processes that affect their lives and the futures of their families, communities, countries and the world.

- The experience and leadership of those who defend women's rights and gender equality in parliaments, unions, cooperatives and community associations.

- The elimination of discriminatory laws, policies and practices and the promotion of legislation, policies and measures aimed at enhancing gender equality and women's empowerment (United Nations, 2015a, 2015b; UN Women, 2018b).

The potential of the SDGs to achieve gender equality and women's empowerment is enhanced by the recognition of the need to address violence against women and girls and to recognize their sexual and reproductive rights (Esquivel \& Sweetman, 2016). According to Razavi (2016), although SDG 5 on 'gender equality' failed to include any reference to 
'women's rights' or 'women's human rights' in its title, it must be considered a step forward because most of the key strategic elements demanded by women's rights organizations were included. However, De la Cruz (2015) stresses that the SDGs indicators and targets still fail to adequately reflect women's priorities in relation to social norms, domestic decisionmaking, taxation and access to services, nor do they analyze women's poverty with respect to access to income, time and property titles. Thus, whereas the SDGs are definitely an improvement on the MDGs from a feminist perspective, a number of weaknesses still remain to be addressed.

\section{The Sustainable Development Goals and tourism from a gender perspective}

In 2015, the United Nations World Tourism Organization (UNWTO) sought to mainstream tourism within all 17 SDGs (UNWTO, 2015, 2017). This was done through the framework of the International Year of Sustainable Tourism for Development (IY2017), however, gender equality was not a key element. As pointed out by the non-governmental organization Equality in Tourism (2017) in response to UNWTO's Discussion Paper on the occasion of the International Year of Sustainable Tourism for Development 2017', the UNWTO failed to grasp the importance of SDG 5 for achieving all of the other Sustainable Development Goals. This is particularly surprising in light of the growing recognition of the importance of gender equality across UN policy and civil society discourse. The UNWTO discussion paper dealt with narrow aspects of gender equality issues in tourism. For instance, while it addressed employment and decent work, it left out discussions of political empowerment and broader questions of structural inequalities. As such, it did not make clear how tourism is meant to contribute to achieving SDG 5, nor did it shed light on the role of institutions in working towards gender equality in tourism. Furthermore, it mixed 'women' and 'youth' in an

\footnotetext{
${ }^{1}$ Available here: http://www.tourism4development2017.org/wp-content/uploads/2017/05/070417 iy2017discussion-paper.pdf
} 
unhelpful conflation, thus diluting the importance of gender issues to both the SDGs and the tourism sector. Moreover, achieving gender equality is not possible without dedicating specific resources to addressing the gender dimensions of tourism; specific budgets are required to advance tourism's contribution to SDG 5. As pointed out by Ferguson (2018, p. 20) "While gender issues were mentioned in a number of speeches and core documents, in reality there has been no substantive support from the secretary-general or programme directors for gender equality to be a priority issue for UNWTO”. Furthermore, the SDGs, "leave no-one behind agenda" underscores the importance of intersectionality, which the UNWTO have failed to adequately consider.

A gender analysis of how tourism relates to all the SDGs means more than merely including the word gender equality or women's empowerment in every SDG. First, it involves recognizing that gender equality is a human right. As Bakas et al. (2018) suggest, many of the issues that women face in tourism are not a matter of increased equality, rather they are human rights issues. The outdated 'add women and mix' strategy frequently applied to tourism, must be replaced with an analysis of women and gender-based power relations when designing, proposing, creating and implementing new tourism policies and initiatives (Rathgeber, 1990; Moser, 1993; Razavi \& Miller, 1995). In other words, gender mainstreaming is a critical concern for implementing tourism development from a gender perspective (Lombardo \& Mergaert, 2013; Lee-Gosselin, Briere \& Ann, 2013; Walby, 2005) in tourism. The following table, based on Moreno (2017b), provides an outline of some valuable avenues to consider when conducting a gender analysis of the Sustainable Development Goals as they relate to tourism. The following section then explores SDGs 6 and 8 in greater detail. 
(INSERT Table 1. The Sustainable Development Goals and Tourism from a Gender Perspective)

\section{Gender and tourism in SDG 6 and SDG 8 and pushing forward}

We now use the examples of SDG 6, 'ensure availability and sustainable management of water and sanitation for all', and SDG 8, 'promote sustained, inclusive and sustainable economic growth, employment and decent work for all', to explore in greater depth the considerations and analysis required for tourism to become a real engine for gender equality and women's empowerment. These two examples are chosen based on the authors' recent in depth research. Gender inequality in employment is one of the major factors preventing decent work in tourism, as the first author discovered while working for UN Women in Cape Verde on their Action Plan for Gender Mainstreaming in tourism; and in Albania where she reviewed the tourism strategy from a gender perspective. Water is the most important natural resource for the future of tourism, and a global tourism concern (Gossling \& Peeters, 2015), although its importance sometimes remains invisible. As the second author discovered in Labuan Bajo, Indonesia, water supply can be a limiting factor for women's participation in tourism.

\section{SDG 6 - Ensure availability and sustainable management of water and sanitation for all}

There is a close relationship between water justice and gender (O' Reily et al., 2009; Ahlers \& Zweeten, 2009; Truelove, 2011; Sultana, 2011) and this has been explored specifically in relation to tourism in a number of destinations (Cole \& Ferguson, 2015; Cole \& Tulis, 2016 Cole, 2017). The tourism industry exerts an enormous strain on water supplies. This generates a range of social problems, not least because local inhabitants often have to compete with the tourism sector over the access, allocation and use of water for their personal 
and domestic needs. Globally, women and girls are responsible for water collection in $80 \%$ of households (UN Women, 2018a). Women suffer to a greater extent when water resources are mismanaged (Hemmingway, 2004). As caregivers, food providers, and health care suppliers, women in many countries are responsible for domestic water provision and management. Their roles are often 'naturalised', unpaid, and unrecognised, which means that women live with issues of water scarcity and contamination on a daily basis. Women's experiences were not monolithic. Nationality, ethnicity, life-stage and occupation all intersected and compounded their experiences of capitalism, patriarchy and water injustice (Cole, 2017).

Women's water work is part of reproductive labour, lacks visibility, and is integral to water supply. Despite this, women are frequently excluded from water distribution policy and decision-making (Cole, 2017) and decisions on "big water issues" such as allocation have been gender blind (UN Women, 2018a). The exclusion of women's voices in the public domain reinforces unequal power dynamics in the household and community. Struggles over water in tourism destinations contribute to gendered processes of empowerment and disempowerment (Cole \& Ferguson, 2015) and women's disproportionate responsibility for water impacts on their ability to work (Cole, 2017). Where tourism receives priority over communities, conflict and resentment will grow, and the potential for tourism to contribute to sustainable development will be undermined. Tourism could have a real impact on SDG 6 by promoting a gender-sensitive water agenda. Infrastructure improvements including the supply of improved water and sanitation is a well-documented positive impact of tourism (Wall \& Mathieson, 2006). However, this is clearly not always the case, with far reaching consequences for women in many destinations. For tourism to contribute to both SDG 5 and SDG 6 it requires firstly the recognition of unpaid and domestic work so the opportunity costs of women's water work can be accounted for. Secondly, affirmative action in water 
governance is needed to address the gender imbalances that drive inequitable water allocation and distribution. This requires strengthening women's voice in the access to and control over water supplies, its administration, pricing and use, and thus their participation in water management and decision-making. However, this increased participation needs to be achieved without increasing women's workloads. Research highlights how leadership in destination management can be improved when a human rights based approach is taken (Cole, 2014).

We know that increased tourism will add to climate change (Lenzen, Sun, Faturay, Ting, Geschke \& Malik, 2018) and that it is those who are most vulnerable, will be the worst off. This is particularly the case in relation to water scarcity. Women face greater health and safety risks when water and sanitation systems are compromised by climate-induced drought (UN Women, 2017). As Cole's (2017) research has highlighted it is women that take on increased domestic and care work to compensate, walking further for collection, eking out meagre supplies and worrying about provision for their families.

The interlinkage of SDG 6 with all the other SDGs is, of course, one of the most apparent after all, water is life. For example, without it we cannot grow food, affecting our food security (SDG 2). When we have to pay for it, it affects our poverty levels (SDG 1) and our health (SDG 3). When there are no piped supplies, we have to collect it - usually girls affecting opportunities for education (SDG 4). As electricity is required to pump water, SDG 7 is affected through the water-energy nexus. Waiting for water to flow down pipes impacts women's opportunities for employment (SDG 8). As discussed by Cole (2017), gender is implicated in all these impacts. A critical gender analysis of water and tourism has the 
potential to not only impact SDGs 5 and 6 but may have ramifications across a host of other SDGs.

\section{SDG 8 -Promote sustained, inclusive and sustainable economic growth, employment and decent work for all}

For tourism stakeholders, the major promise is the creation of employment. In fact, this discourse is at the heart of the trend to promote tourism as a tool for poverty reduction, especially for women (UNWTO \& UN Women, 2011). Globally, some 55\% of tourism workers are women. In some countries, such as Peru or Lithuania, this percentage is over $70 \%$ (Baum, 2013). Women tend to be concentrated in the kinds of occupations that are seen to befit 'feminine characteristics' (Bolles, 1997). As Sinclair (1997) argues, when tourism is not gender aware, tourism converts women's characteristics - that is, 'feminine characteristics' imposed by patriarchy - into merchandise. The 'feminisation' of such types of work has also been associated with strong gender discrimination that is expressed in lower wages and a lack of professional recognition (Ferreira \& Ramos, 2016). As such, women workers' capacity to influence the trade union agenda is severely limited (Cañada, 2016). Within this context, any analysis that integrates the dimension of 'intersectionality' is very important since the construction of their identities as a group of workers entails complex interactions between their gender, class, race and ethnicity (Adib and Guerrier, 2003, McBride, Hebson \& Holgate, 2015; De los Reyes, 2017). As Dyer, McDowell and Batnitzky (2010) discuss, gender and other identities are also implicit in relation to manager and customer requirements who expect "particular gendered performances" (2010, P. 641).

At present, tourism largely fails to provide decent work for many women especially those at the lowest levels of the occupational pyramid. For example, according to Cañada (2015), 
working conditions in hotels' housekeeping departments in Spain, with a high range of migrant women, have given rise to higher rates of accidents and serious injuries than any other jobs in the service industry. This is the case even though they only constitute $30 \%$ of staff. The situation, moreover, has deteriorated because of outsourcing which has led to the loss of professional categories recognized in workers' contracts, leading to a decline in working conditions, status and pay. Thus 'hotel maid' is reduced to categories such as 'cleaner' or 'labourer' (Cañada, in press).

This situation also promotes what Burrel et al. (1997) call 'parking area' training. That is, few opportunities for career progression because of a lack of incentives to invest in more and improved training. However, at the launch of the Spanish version of the Global Report of Women in Tourism in 2012 at Madrid's International Tourism Fair (FITUR), the participants (mainly Spanish women) did not agree with the claim that women in tourism were less well trained than men. On the contrary, several women participants suggested that the main obstacle to decent work for women in tourism is not a lack of training, but a lack of opportunities offered to women and the low social value of a trained woman in the labour market (UNWTO, 2012). Thus, for example, in Portugal, although women work more hours and are better trained than men, they earn less than their male colleagues in the accommodation, travel agencies and tour operation sectors (Carvalho et al., 2014).

Tourism has a great responsibility to ensure gender sensitive decent work. The prevailing discourse on employment in tourism is that the sector supports 1 in 10 jobs globally, many of these jobs are based on gender occupational segregation. In other words, most women's jobs are concentrated at the lower end of the ladder and women remain grossly under-represented at the management level and board level (Equality in Tourism, 2018). Therefore, employing 
women or supporting them to become entrepreneurs does not necessarily change the gendered dynamics in which they are embedded, nor does it necessarily impact their relationships with managers, customers or between co-workers.

Gender sensitive decent work in tourism also means reconciliation between work and family life. This is just as important for men as it is for women workers, enabling men to become equal stakeholders in their families and in care work. When men take their children to school, or finish work early to pick them up as often as women do, then greater flexibility will be offered to all workers and care work will be better shared (Cole, 2018). As Bakas et al. (2018) suggest, when men have care duties, the invisibility of childcare comes to light. Women face challenges when seeking to reach the highest positions in tourism companies not because 'women are doing something wrong' or because of a problem inherent to women. The fact is that most women workers in tourism are located within the lowest rungs of companies' occupational pyramids. Therefore, according to Moreno and Cañada (2018), the feminisation in tourism employment in most cases indicates precariousness and women's lack of power. The disempowerment of women working in tourism weakens women's ability to maximise their potential contribution to the sector, thereby undermining the sustainability of the tourism industry.

\section{Pushing Forward}

The private sector was actively involved in shaping the SDGs (Le Blanc, 2015). As Milne and Gray (2013) suggest, there is an emerging consensus that transnational corporations can, and ought to, contribute to sustainable development by enhancing positive impacts - such as on livelihoods, health and education - and reducing negative impacts - for instance, those related to resource consumption, pollution and human rights violations. However, corporate 
social responsibility (CSR) practices hardly ever address system-wide sustainability challenges, such as overcoming patriarchy. This is particularly the case in large-scale mass tourism which, as Scheyvens et al. suggest, "is dominated by businesses that have built their business models around being short-term operators with high levels of flexibility" (2016, p. 378). While good for profit, this means that these businesses are not invested in destinations and have no interest in their sustainability, in overcoming current inequities, or in advancing gender equality.

In order for businesses to take on responsibility and support the SDGs, either voluntarily or by government regulation, they will require tools to implement, manage and measure their progress. Human rights are the foundation for the SDGs and since the Guiding Principles on Business and Human Rights (United Nations, 2011) some elements of the tourism industry have begun interpreting them (Sandang, 2015). For example, the Tourism Partnership (2014) has suggested that the key areas of concern for hotel businesses are workers' rights, supply chain related issues, community rights, human trafficking risks, customers' rights and governance related issues. The same organization has highlighted global water concerns and argued that hotels should take action (International Tourism Partnership, 2018). As discussed previously in this journal, Human Rights Impact Assessments (HRIAs) are an essential starting point for companies to conduct the necessary due diligence (Cole, 2014). Human Rights Impact Assessments have not yet been standardised to the same degree as environmental impact assessments but a helpful guide for tourism businesses and destinations on how to conduct an HRIA has been produced (Twentyfifty, 2017). Taking human rights based approach is more than a requirement to do no harm: it requires an active commitment to implement key tenets of the UN Guiding Principles, and therefore the SDGs. There are a few limited examples that already exist in tourism, for example lodges that provide water 
(Smith, 2018), and gender awareness training (Equality in Tourism, 2015), in the surrounding communities. However, it is unlikely that most companies will comply with the necessary due diligence requirements without governments' active engagement and enforcement.

Human Rights Impact Assessments are an essential tool for businesses to conduct due diligence to comply with the UN Guiding Principles and understand their impact on their stakeholders. However, they are not specifically gender focused. Gender focused tools exist but they are not adapted for tourism. For example, UN Women and UN Global Compact developed the Women Empowerment Principles (WEPs) as a tool for businesses to empower women across the workplace, marketplace and the community. While they aim to help companies around the world to assess their gender equality performance, they will need to be refined to be useful for many tourism businesses.

Other tools, such as participatory gender audits, can help to identify organizational strengths and challenges in terms of mainstreaming gender. Conducting gender audits would help companies and destinations spotlight gender (in)equality and identify systems, policy, processes and organizational culture that require change. Audits are used for certification, which, although not without critics in tourism (Font \& Harris, 2004), are considered effective instruments to improve companies’ sustainability performance (Ayuso, 2007). Unfortunately, major tourism specific audit and certification schemes, such as Travelife, are yet to include gender equality measures. However, tourism companies that have opted for broader certification schemes, such as B Corp, have shown that it has improved their gender equality (Intrepid Travel, 2018). 
Businesses need to ensure that they are vigilant about complying with SDG target 5.2, 'eliminate all forms of violence against all women and girls in the public and private spheres, including trafficking and sexual and other types of exploitation', through their company policies and procedures. Immense numbers of tourism workers have experienced sexual harassment, so much so that Pritchard (2018) calls it the topic of the next decade.

\section{Conclusion}

The SDGs offer a potentially radical improvement and departure from the MDGs. This is because the SDGs are based on the identification and analysis of the main challenges to gender equality - challenges that the MDGs did not cover. The SDGs include consideration of strategic elements considered essential by women's organisations. Although there has been some debate about the appropriateness of making 'gender equality' a standalone goal, this is explained by the need to secure political will and resource mobilization. Yet, this does not mean that gender equality is not integral to all the other SDGs. The importance of SDG 5 for achieving all of the other SDGs is consistently highlighted by UN policy discourse and civil society. However, the UNWTO and other tourism organisations have yet to acknowledge the need for gender to be mainstreamed. Without tackling gender equality in a meaningful and substantive way, tourism's potential to contribute to all 17 Sustainable Development Goals will be substantively reduced.

Although the SDGs 'talk the talk' on gender equality, when we critically analyze the interconnection between the SDG 5 and other SDGs in the tourism context we shine a light on the gap between rhetoric and reality. Tourism can support the provision of piped water to remote communities, supporting SDG 6, but tourism induced water mismanagement and scarcity affects women in many destinations on a daily basis. Tourism can create jobs and 
support SDG 8 but, as we have uncovered, the nature of tourism jobs frequently does not support SDG 5 or gender mainstreaming. Providing jobs for women alone does not change patriarchal structures, nor does it redistribute unpaid care work, reduce the gender pay gap or combat sexual harassment. The same patriarchal structures, frequently reinforced by tourism policy, dictate water work as women's work, which is unpaid and unaccounted for, and prevents some women from taking jobs.

A human rights approach is embedded in the SDGs and our work starts to explore how to make this a reality for women in tourism. We have suggested the use of Human Rights Impact Assessments, Women's Empowerment Principles and Gender Audits by business as initial steps business can take to play their part towards achieving the SDGs. There is no doubt that all this requires critical thinking, political will, a re-evaluation of priorities, and a dedicated budget. There are gaps, both in the theory and practice, of implementing gender equal and, therefore, sustainable tourism. Some of the areas that require far more detailed analysis include the sexual harassment that women, in particular, face and how to squash it; the intersectional issues women face and how to confront them; and the additional burdens tourism places on women.

There is substantial work needed to further our understanding of how tourism intersects with gender equality and the other SDGs. This will require 1) the collection and analysis of gender sensitive tourism data, 2) training and tourism studies' curricula that integrate gender within sustainable development, 3) tourism practice that draws on feminist gender analysis, 4) more use of intersectional approaches to understand tourism relationship with the SDGs, and, 5) an evaluation of methods utilized to improve gender equality and the dissemination of best 
practice. Much remains to be done, but the benefits, both for the tourism sector and for the global community that stands to benefit far exceed the costs involved.

\section{References}

- Ahlers, R., \& Zweeten, M. (2009). The water question in feminism: water control and gender inequities in a neo-liberal era. Gender, Place and Culture, 16(4): 409-426.

- Adib, A., \& Guerrier, Y. (2003). The interlocking of gender with nationality, race, ethnicity and class: the narratives of women in hotel work. Gender, Work \& Organization, 10(4), 413-432.

- Aitchison, C. (2005). Feminist and gender perspectives in tourism studies: The socialcultural nexus of critical and cultural theories. Tourist studies, 5(3), 207-224..

- Antrobus, P. (2006). Gender Equality in the New Millennium: Goal or Gimmick? Caribbean Quarterly, 52(2/3), 39-50.

- Ariffin, J. (2004). Gender critiques of the Millennium Development Goals: An overview and an assessment. Work presented at the International Council on Social Welfare (ICSW), 31st International Conference on Social Progress and Social Justice, 16-20 August 2004, Kuala Lumpur, Malaysia.

- Ayuso, S. (2007). Comparing Voluntary Policy Instruments for Sustainable Tourism: The Experience of the Spanish Hotel Sector, Journal of Sustainable Tourism, 15:2, 144-159.

- Bakas, F., Costa, C., Durão, M., Carvalho, I., \& Breda, Z. (2018). An uneasy truth: Female tourism managers and organisational gender equality measures in Portugal. In S. Cole (Ed.) Tourism and gender equality: Beyond empowerment (pp.34 - 43). Wallingford: CABI. 
- Baum, T. (2013). International perspectives on women and work in hotels, catering and tourism. Geneva: ILO. Accessed 11 October 2018, http://www.ilo.org/wcmsp5/groups/public/_dgreports/gender/documents/publication/wcms_209867.pdf

- Bidegain Ponte, N., \& Enríquez, C. R. (2016). Agenda 2030: A bold enough framework towards sustainable, gender-just development? Gender \& Development, 24(1), 83-98.

- Bolles, A. (1997). Women as a category of analysis in scholarship on tourism: Jamaican women and tourism employment. In E. Chambers (Ed.) Tourism \& Culture: An Applied Perspective (pp. 77-92). Albany: State University of New York.

- Burrell, J., Manfredi, S., Rollin, H., Price, L., \& Stead, L. (1997). Equal opportunities for women employees in the hospitality industry: a comparison between France, Italy, Spain and the UK. International Journal of Hospitality Management, 16(2), 161-179.

- Caglar, G., Prügl, E., \& Zwingel, S. (Eds.). (2013). Feminist Strategies in International Governance. London and New York: Routledge.

- Cañada, E. (2016). Promote sustained, inclusive and sustainable economic growth, full and productive employment and decent work for all. Transforming Tourism, Goal 8: Decent Work and Economic Growth. Retrieved from http://www.transformingtourism.org/goal-8-decent-work-and-economic-growth.html.

- Cañada, E. (in press). Too precarious to be inclusive? Employment of hotel maids in Spain, Tourism Geographies.

- Carvalho, I., Costa, C., Lykke, N., \& Torres, A. (2014). An Analysis of Gendered Employment in the Portuguese Tourism Sector. Journal of Human Resources in Hospitality \& Tourism, 13(4), 405-429. 
- Chant, S. (2008). The 'Feminisation of Poverty' and the 'Feminisation' of AntiPoverty Programmes: Room for Revision? The Journal of Development Studies, 44(2), 165-197.

- Cole, S., \& Ferguson, L. (2015). Towards a Gendered Political Economy of Tourism and Water. Tourism Geographies, 17(4), 511-528.

- Cole, S. (2014). Tourism and water: from stakeholders to rights holders, and what tourism businesses need to do. Journal of Sustainable Tourism, 22(1), 89-106.

- Cole, S. (2017). Water worries: An intersectional feminist political ecology of tourism and water in Labuan Bajo, Indonesia. Annals of Tourism Research, 67, 14-24.

- Cole, S. (2018). Introduction to S. Cole (Ed) Gender Equality and Tourism. Beyond Empowerment. In S. Cole (Ed.), Gender, Tourism and Empowerment: Women's Critical Voices (pp. 1-11). Wallingford: CABI.

- Cole, S., \& Tulis, I. M. (2016). For the Worry of Water: Water, Women and Tourism in Labuan Bajo. Initial Policy Paper. London: Equality in Tourism. Retrieved from http://equalityintourism.org/wp-content/uploads/2015/11/Stroma-For-the-worry-ofwater-Final.pdf.

- Daly, M. (2005). Gender Mainstreaming in Theory and Practice. Social Politics: International Studies in Gender, State and Society, 12(2), 433-450.

- De La Cruz, C. (2015a). Cambio, Poder y Justicia de Género en la Agenda 2030: Reflexiones para no perdernos en el camino [Change, Power and Gender Justice in the 2030 Agenda: Reflections not to get lost along the way] (Working paper No.1). Madrid: ICEI.

- De los Reyes, P. (2017). Working life inequalities: do we need intersectionality?. Society, Health \& Vulnerability, 8(sup1), 1332858. 
- Denton, F. (2002). Climate change vulnerability, impacts, and adaptation: Why does gender matter? Gender \& Development, 10(2), 10-20.

- Dyer, S., McDowell, L., \& Batnitzky, A. (2010). The impact of migration on the gendering of service work: The case of a West London hotel. Gender, Work \& Organization, 17(6), 635-657.

- Equality in Tourism (2015, November). Lessons from Zala Beach Lodge. Equality in Tourism. Retrieved from http://equalityintourism.org/working-towards-genderequality-and-empowerment-lessons-from-zalala-beach-lodge-mozambique-2/.

- Equality in Tourism. (2017, July). UNWTO Discussion Paper on the occasion of the International Year of Sustainable Tourism for Development 2017: Equality in Tourism Comment. Equality in Tourism. Retrieved from $\underline{\text { http://equalityintourism.org/equality-in-tourism-responds-to-unwto-discussion-paper- }}$ on-the-occasion-of-the-international-year-of-sustainable-tourism-for-development$\underline{2017 /}$

- Equality in Tourism (2018). Sun, Sand and Ceilings: Women in Tourism and Hospitality Board Rooms 2018. Retrieved http://equalityintourism.org/wpcontent/uploads/2018/11/sun-sand-and-ceilings-2018.pdf.

- Esquivel, V., \& Sweetman, C. (2016). Gender and the Sustainable Development Goals. Gender \& Development, 24(1), 1-8.

- FAO. (2015). Globefish Research Programme: The role of women in the seafood industry. Rome: FAO. Retrieved from http://www.fao.org/3/a-bc014e.pdf

- Feng, X. (2013). Women's work, men's work: Gender and tourism among the Miao in rural China. Anthropology of Work Review, 34(1), 2-14.

- Ferguson, L. (2009). Analysing the Gender Dimensions of Tourism as a Development Strategy. Retrieved from https://eprints.ucm.es/10237/1/PP_03-09.pdf 
- Ferguson, L. (2010a). Interrogating 'gender' in development policy and practice: The World Bank, tourism and microenterprise in Honduras. International Feminist Journal of Politics, 12(1), 3-24.

- Ferguson, L. (2010b). Tourism development and the restructuring of social reproduction in Central America. Review of International Political Economy, 17(5), 860-888.

- Ferguson, L. (2011). Promoting Gender Equality and Empowering Women? Tourism and the Third Millennium Development Goal. Current Issues in Tourism, 14(3), 235249.

- Ferguson, L. (2014). “This is our gender person": the messy business of being a gender expert in international development', International Feminist Journal of Politics, 17:3, 380-397, DOI 10.1080/14616742.2014.918787.

- Ferguson, L. (2018). Gender equality and Tourism: the global policy context. In S. Cole (Ed) Gender Equality and Tourism. Beyond Empowerment (pp. 14-22). Wallingford: CABI.

- Ferguson, L., \& Moreno, D. (2015). Gender and sustainable tourism: reflections on theory and practice. Journal of Sustainable Tourism, 23(3), 401-416.

- Ferguson, L., \& Moreno, D. (2016). Gender Expertise and the Private Sector: Navigating the Privatization of Gender Equality Funding. In M. Bustelo, L. Ferguson, \& M. Forest (Eds.), The Politics of Feminist Knowledge Transfer: Gender Training and Gender Expertise (pp. 62-79). Basingstoke: Palgrave Macmillan.

- Fernández-Layos, A., \& Ruiz, M. (2011). Claves para la incidencia política en derechos sexuales y reproductivos en África [Keys to political advocacy on sexual and reproductive rights in Africa]. Madrid: Red de MujeresAfricanas y Españolas por un Mundo Mejor. 
- Ferreira Freire Guimaraes, C.R., \& Ramos Silva, J. (2016). Pay gap by gender in the tourism industry of Brazil. Tourism Management, 52, 440-450.

- Figueroa-Domecq, C., Pritchard, A., Segovia-Pérez, M., Morgan, N., \& VillacéMolinero, T. (2015). Tourism gender research: A critical accounting. Annals of Tourism Research, 52, 87-103.

- Font, X., \& Harris, C. (2004). Rethinking standards from green to sustainable. Annals of Tourism Research, 31(4), 986-1007.

- Fukuda-Parr, S. (2016). From the Millennium Development Goals to the Sustainable Development Goals: shifts in purpose, concept, and politics of global goal setting for development. Gender \& Development, 24(1), 43-52.

- Gentry, K. (2007). Belizean women and tourism work: Opportunity or impediment? Annals of Tourism Research, 34(2), 477-496.

- Gibson, H. (2001). Gender in Tourism: Theoretical perspectives. In Y. Apostolopoulos, S. Sonmez, \& D. Timothy (Eds.), Women as Producers and Consumers of Tourism in Developing Countries (pp. 19-43). Westport: Praeger.

- Gössling, S., \& Peeters, P. (2015). Assessing tourism's global environmental impact 1900-2050. Journal of Sustainable Tourism, 23(5), 639-659.

- Hardy, A., Beeton, R. J., \& Pearson, L. (2002). Sustainable tourism: An overview of the concept and its position in relation to conceptualisations of tourism. Journal of sustainable tourism, 10(6), 475-496.

- Harvey, MJ.,Hunt, J., \& Harris,CC. (1995). Gender and community tourism dependence level. Annals of Tourism Research, 22(2), 349-366.

- Hemmingway, S. (2004). The impact of Tourism on the Human Rights of Women in South East Asia. International Journal of Human Rights, 8(3), 275-304. 
- Hoard, S. (2015). Gender Expertise in Public Policy: Towards a Theory of Policy Success. Abingdon and New York: Palgrave Macmillan.

- Huete, R., Brotons, M., \& Sigüenza, M. C. (2016). La desigualdad entre mujeres y hombres en el sector hostelero español [Inequality between Women and Men in the Spanish Hospitality Sector]. Estudios y Perspectivas en Turismo, 25(1), 73-87.

- International Tourism Partnership. (2014). Know How Guide: Human Rights \& the Hotel Industry. Retrieved from http://www.greenhotelier.org/wpcontent/uploads/2015/01/Know-How-Guide-Human-Rights.pdf

- International Tourism Partnership. (2018). Water Stewardship For Hotel Companies. Retrieved from https://www.tourismpartnership.org/download/2212/.

- Intrepid Travel (2018). How B Corp certification changes the way we operate. Retrieved from https://www.intrepidtravel.com/uk/b-corp

- Iverson, K. (2000). The paradox of the contented female manager: an empirical investigation of gender differences in pay expectation in the hospitality industry. Hospital Management, 19(1), 22-51.

- Jordan, F. (1997). An occupational hazard? Sex segregation in tourism employment. Tourism Management, 18(8), 525-534.

- Kabeer, N. (2015). Tracking the gender politics of the Millennium Development Goals: struggles for interpretive power in the international development agenda. Third World Quarterly, 36(2), 377-395.

- Kinnaird, V., \& Hall, DR. (1994). Tourism: a gender analysis. Chichester: John Wiley \& Sons Ltd.

- Kinnaird, V., \& Hall, DR. (1996). Understanding tourism processes: A gender- aware framework. Tourism Management, 17(2), 95-102. 
- Knight, D., \& Cottrell, S. (2016). Evaluating tourism-linked empowerment in Cuzco, Peru. Annals of Tourism Research, 56, 32-47.

- Ladkin, A. (2011). Exploring tourism labor. Annals of Tourism Research, 38(3), 1135-1155.

- Lakovidou, O., \& Turner, C (1995). The female gender in Greek agrotourism. Annals of Tourism Research, 22(2), 481-484.

- Le Blanc, D. (2015). Towards integration at last? The Sustainable Development Goals as a network of targets. Sustainable Development, 23(3), 176-187.

- Lee-Gosselin, H., Briere, S., \& Ann, H. (2013). Resistances to gender mainstreaming in organizations: Toward a new approach. Gender in Management: An International Journal, 28(8), 468-485.

- $\quad$ Lenzen, M., Sun, YY., Faturay, F., Ting, YP., Geschke, A., \& Malik, A. (2018). The carbon footprint of global tourism. Nature Climate Change, 8(6): 522-531.

- Lombardo, E., \& Mergaert, L. (2013). Gender mainstreaming and resistance to gender training: A framework for studying implementation. NORA-Nordic Journal of Feminist and Gender Research, 21(4), 296-311.

- McBride, A., Hebson, G., \& Holgate, J. (2015). Intersectionality: are we taking enough notice in the field of work and employment relations?. Work, employment and socety, 29(2), 331-341.

- Milne, M. J., \& Gray, R. (2013). Whither ecology? The triple bottom line, the global reporting initiative and corporate sustainability reporting. Journal of Business Ethics, $118(1), 13-29$.

- Mooney, S. (2018). Illuminating intersectionality for tourism researchers. Annals of Tourism Research 72 (C), 175-176. 
- Moreno, D. (2017a). Turismo y Género: un enfoque esencial en un contexto de desarrollo sostenible y responsable del turismo (Unpublished doctoral dissertation). Universidad Complutense, Madrid.

- Moreno, D. (2017b). ODS, Turismo y Género: fundamentos y recomendaciones para la educación y sensibilización [SDGs, Tourism and Gender: foundations and recommendations for education and awareness]. Córdoba: El Centro de Iniciativas para la Cooperación Batá.

- Moreno, D. (2018a). Feminist Perspectives in the Development of Action Plans for Tourism. In S. Cole (Ed.), Gender, Tourism and Empowerment: Women's Critical Voices (pp. 14-22). Wallingford: CABI.

- Moreno, D. (2018b). Cómo elaborar un diagnostic de género y turismo en un context rural [How to elaborate a diagnostic on gender and tourism in a rural context]. Retrieved from http://www.albasud.org/publ/docs/84.pdf

- Moreno, D., \& Cañada, E. (2018). Gender Dimension in Tourism Work. Retrieved from http://www.albasud.org/publ/docs/81.en.pdf

- Moser, C. O. (1993). Gender planning and development: Theory, practice and training. London: Routledge.

- Moswete, N., \& Lacey, G. (2015). 'Women cannot lead': Empowering women through cultural tourism in Botswana. Journal of Sustainable Tourism, 23(4), 600617.

- Movono, A., \& Dahles, H. (2017). Female empowerment and tourism: a focus on businesses in a Fijian village, Asia Pacific. Journal of Tourism Research, 22(6), 681692.

- Mujeres en Red. (2005). Reflexiones desde el feminismo sobre los Objetivos del Milenio. Comité Regional Pekín+10 - América Latina. Mujeres en Red [Reflections 
from feminism on the Millennium Development Goals- Rights - Beijing + 10 -]. Retrieved from http://www.mujeresenred.net/IMG/article_PDF/article_a119.pdf

- Muñoz-Bullón, F. (2009). The gap between male and female pay in the Spanish tourism industry. Tourism Management, 30(5), 638-649.

- Mukhopadhyay, M. (2013). Mainstreaming Gender or Reconstituting the Mainstream? Gender Knowledge in Development. Journal of International Development, 26(3), 356-367.

- Norris, J., Wall, G., Cooper, C., \& Lockwood, A. (1994). Gender and tourism. Progress in tourism, recreation and hospitality management, 6, 57-78.

- Nozawa, H. (1995). Female professionals in the Japanese tourism industry. Annals of Tourism Research, 22(2), 484-487.

- O’Reilly, K., Halvorson, S., Sultana, F., \& Laurie, N. (2009). Introduction: global perspectives on gender-water geographies. Gender, Place and Culture, 16(4), 381385.

- Panta, S. K., \& Thapa, B. (2017). Entrepreneurship and women's empowerment in gateway communities of Bardia National Park, Nepal. Journal of Ecotourism, 17(1), $20-42$.

- Post-2015 Women's Coalition. (2015). Feminist Sustainable Development: A Transformative Alternative for Gender Equality, Development and Peace. Retrieved from

http://www.peacewomen.org/sites/default/files/Post2015WomensCoalitionVisionStat ement_FINAL.pdf

- Pritchard, A. (2018). Predicting the next decade of tourism gender research. Tourism management perspectives, 25, 144-146. 
- Pritchard, A., Morgan, N., Ateljevic, I., \& Harris, C. (2007). Editors' Introduction:

Tourism, Gender, Embodiment and Experience. En A. Pritchard, N. Morgan, I.

Ateljevic \& C. Harris (Eds.), Tourism and Gender: Embodiment, Sensuality and Experience (pp. 1-12). Wallingford: CABI.

- Purcell, K. (1996). The Relationship between Career and Job Opportunities: Women's Employment in the Hospitality Industry as a Microcosm of Women's Employment. Women in Management Review, 11(5), 17-24.

- Ramos, A., \& Prideaux, B. (2014). Indigenous ecotourism in the Mayan rainforest of Palenque: empowerment issues in sustainable development. Journal of Sustainable Tourism, 22(3), 461-479.

- Razavi, S. (2016). The 2030 Agenda: challenges of implementation to attain gender equality and women's rights. Gender \& Development, 24(1), 25-41.

- Sandang, Y. (2015). After UNGPs on Human Right and Business: Study on Several Follow-Up in Tourism. In Developments of the New Tourism Paradigm in the Asia Pasific Region, (pp. 277-280). Asia Pasific Tourism Association (APTA).

- Scheyvens, R. (2007). Ecotourism and gender issues. Critical issues in ecotourism, (pp. 185-213).

- Scheyvens, R., Banks, G., \& Hughes, E. (2016). The Private Sector and the SDGs: The Need to Move Beyond 'Business as Usual'. Sustainable Development, 24, 371382.

- Sinclair, M. (1997). Gendered work in tourism: Comparative perspectives. En M. Sinclair (Ed.), Gender, Work and Tourism, (pp. 220-234). New York: Routledge.

- Skalpe, O. (2007). The CEO gender pay gap in the tourism industry - Evidence from Norway. Tourism Management, 28(3), 845-853. 
- Smith, J. (2018). Transforming Tourism Realising the potential for sustainable Tourism. Wallingford: CABI.

- Standing, H. (2004). Gender, Myth and Fable: The Perils of Mainstreaming in Sector Bureaucracies. IDS Bulletin, 35(4), 82-88.

- Suárez, P., Barquín, R., Jiménez, G., \& Alfonso, M. J. (2016). Teorías y métodos en la investigación sobre turismo, género y mujeres en Iberoamérica: un análisis bibliográfico [Theories and methods in research on tourism gender and women in Ibero-america: a bibliographic analysis]. Cuadernos de Turismo, (38), 485-501.

- Sultana, F. (2011). Suffering for water, suffering from water: Emotional geographies of resource access, control and conflict. Geoforum, 42(2), 163-172.

- Swain, M. (1993). Women producers of ethnic arts. Annals of Tourism Research, 20(1), 32-51.

- Swain, M. (1995). Gender in tourism. Annals of Tourism Research, 22(2), 247-266.

- Swain, M., \& Swain, M. T. B. (2004). An ecofeminist approach to ecotourism development. Tourism Recreation Research, 29(3), 1-6.

- Swain, M. (2007). On the Road to a Feminist Tourism Studies. In D. Nash (Ed.), The Study of Tourism: Anthropological and Sociological Beginnings (pp. 197-208). Oxford/Amsterdam: Elsevier.

- Swain, M., \& Hall, M. (2007). Gender analysis in tourism: Personal and global dialectics. En I. Ateljevic, A. Pritchard \& N. Morgan (Eds.), The Critical Turn in Tourism Studies: Innovative Research Methodologies (pp. 91-104). Oxford: Elsevier.

- Thrane, C. (2008). Earnings differentiation in the tourism industry: Gender, human capital and socio-demographic effects. Tourism Management, 29(3), 514-524.

- Trans, L., \& Walter, P. (2014). Ecotourism, gender and development in northern Vietnam. Annals of Tourism Research, 44, 116-130. 
- Truelove, Y. (2011). (Re-) conceptualizing water inequality in Delhi, India through a feminist political ecology framework. Geoforum, 42(2), 143-152.

- Tucker, H., \& Boonabaana, B. (2012). A critical analysis of tourism, gender and poverty reduction. Journal of Sustainable Tourism, 20(3), 437-455.

- TwentyFifty (2017). Human Rights Assessments in the Tourism Sector: A data collection guide for practitioners. Retrieved from https://www.twentyfifty.co.uk/en/news-views/publications/2017/human-rightsassessments-in-the-tourism-sector/.

- UNIFEM United Nations Development Fund for Women. (2000). Progress of the World's Women 2000. New York: UNIFEM.

- United Nations. (2000). Millennium Declaration. A/RES/55/2. Resolution adopted by the General Assembly on 8 September 2000. New York: United Nations.

- United Nations. (2011). Guiding Principles on Business and Human Rights Guiding Principles on Business and Human Rights.

- United Nations (2015a). Draft outcome document of the United Nations summit for the adoption of the post-2015 development agenda. A/RES/69/315. Resolution adopted by the General Assembly on 1 September 2015. New York: United Nations.

- United Nations. (2015b). Transforming our world: the 2030 Agenda for Sustainable Development. A/RES/70/1. Resolution adopted by the General Assembly on 25 September 2015. New York: United Nations

- UN Women. (2017). In Focus: Climate action by, and for, women. Retrieved from http://www.unwomen.org/en/news/in-focus/climate-change.

- UN Women. (2018a). Gender equality in the 2030 Agenda: Gender-responsive water and sanitation systems. Retrieved from http://www.unwomen.org/en/digital- 
library/publications/2018/6/issue-brief-gender-responsive-water-and-sanitationsystems.

- UN Women. (2018b). Turning promises into action: gender equality in the 2030 agenda for sustainable development. Retrieved from http://www.unwomen.org//media/headquarters/attachments/sections/library/publications/2018/sdg-reportgender-equality-in-the-2030-agenda-for-sustainable-development-2018en.pdf?la $=$ en $\& v s=4332$

- UNWTO. (2012). Informe del taller sobre el empoderamiento de las mujeres en el sector turístico como motor de desarrollo. Madrid: UNWTO.

- UNWTO. (2013). Guidebook: Sustainable Tourism for Development. Madrid: UNWTO.

- UNWTO. (2015, September 28). UNWTO welcomes the adoption of the Sustainabl Development Goals. UNWTO. Retrieved from http://media.unwto.org/press$\underline{\text { release/2015-09-28/unwto-welcomes-adoption-sustainable-development-goals }}$

- UNWTO. (2017). Tourism and the Sustainable Development Goals - Journey to 2030. Madrid: UNWTO.

- UNWTO. (2018). Tourism and the Sustainable Development Goals - Good Practices in the Americas. Madrid: UNWTO.

- UNWTO \& UN Women. (2011). Global Report on Women in Tourism 2010. Madrid: UNWTO.

- Vandegrift, D. (2008). This isn't paradise - I work here: Global restructuring, the tourism industry, and women workers in Caribbean Costa Rica. Gender and Society, 2(6), 778-798.

- Walby, S. (2005). Gender mainstreaming: productive tensions in theory and practice. Social Politics: International Studies in Gender, State and Society, 12(3), 321-343. 
- Wall, G., \& Mathieson, A. (2006). Tourism: Change, Impacts and Opportunities. Pearson Education Limited, Harlow.

- Wilkinson, PF, \& Pratiwi, W. (1995). Gender and tourism in an Indonesian village. Annals of Tourism Research, 22(2), 283-299. 


\begin{tabular}{|c|c|}
\hline SDGs & Gender Persective Inputs \\
\hline $\begin{array}{l}\text { SDG } 1 \text { - End poverty in all its } \\
\text { forms everywhere }\end{array}$ & $\begin{array}{l}\text { There is a complex link between poverty, and gender } \\
\text { equality, which is not based on job creation and income } \\
\text { alone. The link between poverty alleviation, tourism and } \\
\text { gender equality requires a broad analysis from a gender } \\
\text { perspective including exploring the feminization of poverty } \\
\text { in tourism i.e. tourism income does not necessarily free } \\
\text { women from gender based violence or give them equal } \\
\text { power. }\end{array}$ \\
\hline $\begin{array}{l}\text { SDG } 2 \text { - End hunger, achieve } \\
\text { food security and nutrition, } \\
\text { Promote sustainable } \\
\text { agriculture }\end{array}$ & $\begin{array}{l}\text { The importance of food sovereignty and safety is } \\
\text { complicated when communities are involved with tourism. } \\
\text { Women are frequently responsible for food production and } \\
\text { maintaining a supply of food for their family while hosting } \\
\text { tourists can be a challenge. Producing food for tourists' } \\
\text { tastes can compete for land with primary production for } \\
\text { local people. Furthermore, women frequently do not have } \\
\text { land certificates but are the first to lose out to usufruct rights } \\
\text { to tourism developers. }\end{array}$ \\
\hline $\begin{array}{l}\text { SDG } 3 \text { - Ensure healthy lives } \\
\text { and promote well-being for } \\
\text { all at all ages }\end{array}$ & $\begin{array}{l}\text { Limited reproductive and sexual rights are exacerbated by } \\
\text { sex tourism. Increases in sexually transmitted diseases, } \\
\text { unwanted pregnancies, rape and sexual exploitation of } \\
\text { women, girls and boys, all need to be recognized and } \\
\text { addressed. Increased health spending for the benefit of local } \\
\text { populations, including gender-based violence, safe sex }\end{array}$ \\
\hline
\end{tabular}




\begin{tabular}{|c|c|}
\hline & $\begin{array}{l}\text { education and provision, and reduced stigmatization of HIV, } \\
\text { could be promoted though tourism. }\end{array}$ \\
\hline $\begin{array}{l}\text { SDG } 4 \text { - Ensure inclusive and } \\
\text { equitable quality education } \\
\text { and promote lifelong learning } \\
\text { for all }\end{array}$ & $\begin{array}{l}\text { Developing a tourism curriculum from a gender perspective } \\
\text { is a challenge, and rarely exists, even though more women } \\
\text { than men study and teach tourism! Tourist education has } \\
\text { lacked an exploration of the roles, experiences and } \\
\text { contributions of women within tourism, or a consideration of } \\
\text { the barriers that prevent women from reaching their potential } \\
\text { (Pritchard 2017). Cultural factors, reproductive labor roles } \\
\text { and basic education deficits frequently limit opportunities } \\
\text { for community tourism education for women. }\end{array}$ \\
\hline $\begin{array}{l}\text { SDG } 5 \text { - Achieve gender } \\
\text { equality and empower all } \\
\text { women and girls }\end{array}$ & $\begin{array}{l}\text { Including a gender perspective in tourism is a clear and } \\
\text { concrete action not only to reduce poverty, but also to invest } \\
\text { smartly in that reduction. Tourism models, including those } \\
\text { that are promoted as less harmful, will not be sufficiently } \\
\text { sustainable and accountable if a gender-based approach and } \\
\text { the empowerment of women are not incorporated in a real } \\
\text { and sustained way. This implies adjusting all declarations, } \\
\text { instruments of planning, management and analysis related to } \\
\text { tourism. }\end{array}$ \\
\hline $\begin{array}{l}\text { SDG } 6 \text { - Ensure the } \\
\text { availability and sustainable } \\
\text { management of water and } \\
\text { sanitation for all }\end{array}$ & $\begin{array}{l}\text { Women bear the brunt of water scarcity when communities } \\
\text { lose out to the tourism industry for water supplies. A } \\
\text { Human Rights approach to water management would ensure } \\
\text { a fairer distribution of water. Women's voices in the access, } \\
\text { use, control and administration of water is critical. }\end{array}$ \\
\hline
\end{tabular}




\begin{tabular}{|c|c|}
\hline $\begin{array}{l}\text { SDG } 7 \text { - Ensure access to } \\
\text { affordable, reliable, } \\
\text { sustainable and modern } \\
\text { energy for all }\end{array}$ & $\begin{array}{l}\text { The tourism industry needs a lot of power. To be } \\
\text { sustainable, it must prioritise the use of renewable sources of } \\
\text { energy. Besides promoting its own self-interest and } \\
\text { sustainability, it can also promote the use of reliable green } \\
\text { sources of energy in the communities where it is based. } \\
\text { Increased access to electricity will also promote womens } \\
\text { education and security, as well as the creation of new jobs. }\end{array}$ \\
\hline $\begin{array}{l}\text { SDG } 8 \text { - Promote sustained, } \\
\text { inclusive and sustainable } \\
\text { economic growth, } \\
\text { employment and decent work } \\
\text { for all }\end{array}$ & $\begin{array}{l}\text { A gender perspective in tourism employment policies places } \\
\text { emphasis on salary gaps, sexual abuse and harassment by } \\
\text { colleagues and tourists, and fosters female workers' } \\
\text { participation and decision-making. }\end{array}$ \\
\hline $\begin{array}{l}\text { SDG } 9 \text { - Build resilient } \\
\text { infrastructure, promote } \\
\text { inclusive and sustainable } \\
\text { industrialisation and foster } \\
\text { innovation }\end{array}$ & $\begin{array}{l}\text { Awareness of the infrastructure used by women is essential } \\
\text { to ensure their safety; without due consideration, tourism } \\
\text { development can limit this. Since innovation implies } \\
\text { transformation, tourism should embrace the transformational } \\
\text { opportunities promoted by gender equality. }\end{array}$ \\
\hline $\begin{array}{l}\text { SDG } 10 \text { - Reduce inequality } \\
\text { within and among countries }\end{array}$ & $\begin{array}{l}\text { Better regulation and monitoring of global financial markets } \\
\text { and better representation of developing countries in } \\
\text { international decision-making will reduce inequality. } \\
\text { Therefore, it would be very useful to know the gender } \\
\text { impact of foreign direct investment in the tourist sector and } \\
\text { the fiscal benefits that tourism enjoys in many developing } \\
\text { countries. }\end{array}$ \\
\hline
\end{tabular}




\begin{tabular}{|c|c|}
\hline $\begin{array}{l}\text { SDG } 11 \text { - Make cities and } \\
\text { human settlements inclusive, } \\
\text { safe, resilient and sustainable }\end{array}$ & $\begin{array}{l}\text { The guaranteed safety of women, both locals and tourists is } \\
\text { required if tourism is to be sustainable. Over-tourism is a } \\
\text { significant issue for many cities, as yet there has been no } \\
\text { gender analysis of the problems experienced by citizens as a } \\
\text { result of this problem. }\end{array}$ \\
\hline $\begin{array}{l}\text { SDG } 12 \text { - Ensure sustainable } \\
\text { consumption and production } \\
\text { patterns }\end{array}$ & $\begin{array}{l}\text { Ensuring sustainable production requires the integration of a } \\
\text { gender analysis in the value chain to consolidate fair trade } \\
\text { and ensure women's participation. }\end{array}$ \\
\hline $\begin{array}{l}\text { SDG } 13 \text { - Take urgent action } \\
\text { to combat climate change and } \\
\text { its impacts }\end{array}$ & $\begin{array}{l}\text { Climate change will have a greater impact on women than } \\
\text { men (Denton, 2002). According to UN Women (2018) } \\
\text { women and children are } 14 \text { times more likely to die in a } \\
\text { disaster than men. Women's voice is essential in climate } \\
\text { change resilience and tourism related planning, } \\
\text { policymaking and implementation. }\end{array}$ \\
\hline $\begin{array}{l}\text { SDG } 14 \text { - Conserve and } \\
\text { sustainably use the oceans, } \\
\text { seas and marine resources for } \\
\text { sustainable development }\end{array}$ & $\begin{array}{l}47 \text { percent of the } 120 \text { million people who work in the } \\
\text { capture and post-harvest fisheries sectors are women (FAO, } \\
2015 \text { ) so their voice in the sustainable use of the oceans must } \\
\text { move beyond them as products for tourism. }\end{array}$ \\
\hline $\begin{array}{l}\text { SDG } 15 \text { - Protect, restore and } \\
\text { promote sustainable use of } \\
\text { terrestrial ecosystems and halt } \\
\text { biodiversity loss }\end{array}$ & $\begin{array}{l}\text { Loss of land through tourism is well documented. Land } \\
\text { certification for women is critical and must not be } \\
\text { compromised by tourism development. Women's role as } \\
\text { custodians of biodiversity needs to be nurtured and given } \\
\text { greater recognition. }\end{array}$ \\
\hline SDG 16 - Promote & In order to promote peaceful and inclusive societies, it is \\
\hline
\end{tabular}




\begin{tabular}{|c|c|}
\hline $\begin{array}{l}\text { and inclusive societies, } \\
\text { provide access to justice for } \\
\text { all and build inclusive } \\
\text { institutions }\end{array}$ & $\begin{array}{l}\text { vital to understand that structural inequalities are mainly } \\
\text { produced by patriarchy, which perpetuates gender-based } \\
\text { violence in the form of physical, economic, psychological, } \\
\text { sexual and political abuse. Therefore, the identification and } \\
\text { implementation of measures to end gender-based violence, } \\
\text { embedded in or related to tourism, must be a priority for } \\
\text { achieving SDG } 16 \text {. }\end{array}$ \\
\hline $\begin{array}{l}\text { SDG } 17 \text { - Strengthen the } \\
\text { means of implementation and } \\
\text { revitalize the global } \\
\text { partnership for sustainable } \\
\text { development }\end{array}$ & $\begin{array}{l}\text { According to UNWTO (2013), more than half of the poorest } \\
\text { countries in the world use tourism as an instrument for } \\
\text { poverty reduction. The UNWTO needs to recognise the } \\
\text { critical contribution that Civil Society Organisations, } \\
\text { particularly women's groups, will make to their policy and } \\
\text { agenda. The inclusion of women's voices will give more } \\
\text { value to multi-stakeholder partnerships and public- private } \\
\text { sector initiatives. }\end{array}$ \\
\hline
\end{tabular}




\begin{tabular}{|c|c|}
\hline Reviewers comments & Our changes/responses \\
\hline $\begin{array}{l}\text { The paper tends to generalise women. It would } \\
\text { be good to make clear the point that women } \\
\text { are different and face various challenges and } \\
\text { opportunities. } \\
\text { I believe it is necessary to try and avoid } \\
\text { generalizing people and to more clearly } \\
\text { recognize various positions of contextual } \\
\text { realities of women. }\end{array}$ & $\begin{array}{l}\text { We have added a paragraph to the introduction } \\
\text { to explain and underscore the importance of } \\
\text { intersectionality (P3) and this point has been } \\
\text { made again in reference to water (P 10) and is } \\
\text { returned to again in the conclusion. }\end{array}$ \\
\hline $\begin{array}{l}\text { It would have been interesting to bring out case } \\
\text { studies how long in terms of distance some } \\
\text { women in tourism contexts walk to access } \\
\text { water and other challenges they face. }\end{array}$ & $\begin{array}{l}\text { This is detailed in the referenced article and } \\
\text { there is not the space in this paper to go in to } \\
\text { the details. }\end{array}$ \\
\hline $\begin{array}{l}\text { Given that the 2nd report on Women in tools is } \\
\text { not yet out, I don't think the authors should } \\
\text { raise it in the paper }\end{array}$ & Reference to the report has been erased. \\
\hline $\begin{array}{l}\text { The manuscript needs to be completely edited } \\
\text { as there are still several typos and grammatical } \\
\text { errors. } \\
\text { The manuscript would benefit from a reworking } \\
\text { of the general flow in order to add to a level of } \\
\text { refinement and revision required to meet the } \\
\text { standard of the Journal. }\end{array}$ & $\begin{array}{l}\text { The entire paper has been edited again for flow } \\
\text { and precision of the arguments and use of } \\
\text { English. We believe it now meets the standards } \\
\text { of the journal. }\end{array}$ \\
\hline $\begin{array}{l}\text { The gap that the recommendation of these } \\
\text { tools is making needs to be made clear. I feel } \\
\text { the tools just appeared suddenly without clear } \\
\text { justification. } \\
\text { In addition, the authors could position the tools } \\
\text { within the paper more clearly and they require } \\
\text { first to be introduced and refined. }\end{array}$ & $\begin{array}{l}\text { The entire section on the suggested tools has } \\
\text { been reworked. We hope it is now obvious why } \\
\text { we have made these suggestions. Thanks to the } \\
\text { reviewers we re-examined the suggested tools } \\
\text { and decided to cut out the gender gap analysis, } \\
\text { which has given us more space to show how } \\
\text { the other tools can be adapted/are being used } \\
\text { in tourism, with links to industry's application } \\
\text { of them. }\end{array}$ \\
\hline $\begin{array}{l}\text { There is additional feminist literature that } \\
\text { needs to be included and referenced that } \\
\text { would potentially help the author(s). }\end{array}$ & $\begin{array}{l}\text { We have added this feminist literature related } \\
\text { with gender mainstreaming (Standing, 2004; } \\
\text { Daly, 2005; Caglar, Prügl \& Zwingel, 2013; } \\
\text { Mukhopadhyay, 2013; Hoard, 2015) }\end{array}$ \\
\hline $\begin{array}{l}\text { It would be interesting for the reader to be } \\
\text { offered more explanation about how this } \\
\text { discussion more critically relates to tourism } \\
\text { organizations and policy in terms of gender for } \\
\text { example }\end{array}$ & We have added more (see page 10 ) \\
\hline 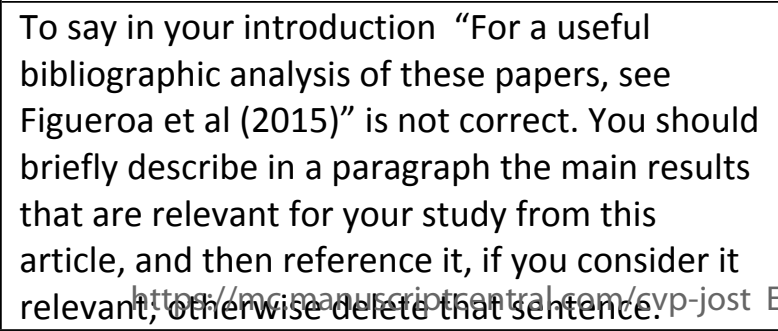 & It has been deleted. \\
\hline
\end{tabular}


Please explain further what do you mean with

This has been changed (see page 2)

this statement "A great deal of gender and tourism analysis is only just emerging in the tourism sector's 'field reality' and, therefore, at the global level there remains a lack of gender sensitive tourism policies, alongside a dearth of gender sensitive tourism stakeholders".

This seems to be the aim of your article "The purpose of this paper is to highlight the importance of SDG 5, gender equality, for the development of tourism and its relationship to the other SGDs". Could you briefly elaborate a little bit more, since it seems you have other objectives in your project. It might be interesting to include research questions too.

The main problem of this article is the implementation of a specific methodology in order to evaluate the SDG. More information about methodology needs to be included. Maybe a content analysis or a critical analysis of the SDG and the implementation of theoretical frameworks in tourism and gender would improve method and results. Other suggestions

The first paragraph on page 4 has been entirely rewritten to make the objectives of our paper far clearer.
This is out of the scope the objectives of our paper which are clearly laid out on page 4 . However, this is a great idea for the next paper!
The reworking of the paper should have answered the other comments and queries. The reviewer's comments have helped us clarify the purpose of the paper and thus its structure. 